https://helda.helsinki.fi

\title{
A-Legal Irruptions and Spatial Revolutions
}

\section{Minkkinen, Panu}

2016

Minkkinen , P 2016 , ' A-Legal Irruptions and Spatial Revolutions ' , Jurisprudence , vol. 7 , no. 2 , pp. 401-408 . https://doi.org/10.1080/20403313.2016.1188506

http://hdl.handle.net/10138/173393

https://doi.org/10.1080/20403313.2016.1188506

submittedVersion

Downloaded from Helda, University of Helsinki institutional repository.

This is an electronic reprint of the original article.

This reprint may differ from the original in pagination and typographic detail.

Please cite the original version. 


\section{A-legal irruptions and spatial revolutions}

Panu Minkkinen

Faculty of Law

P.O. Box 4

FI-00014 University of Helsinki

Finland

Email panu.minkkinen@helsinki.fi

Writing a conventional review of Hans Lindahl's recent book would be an ungrateful task. As a theoretical monograph, Fault Lines of Globalization is as rich as the festive foods of an Easter meal trying to make up for a long period of pious fasting. So compressing all its richness into a few pages would not only be impossible, but it would also do injustice to the wealth of original and compelling insights included here. Those of us who have followed Lindahl's work closely over the last few years will recognize familiar themes. ${ }^{1}$ But the book is also different. Fault Lines is an elegant and refined theoretical conclusion after a long period of scholarly incubation and, no doubt, a major milestone for its author, as well.

And so it is, I feel, both right and proper that, instead of attempting the impossible, that is, instead of trying to say everything that there is to say, a contribution to a review symposium should take some individual aspect of Lindahl's book and try to comment on it in the hope of advancing the more general debates that the book addresses.

${ }^{1}$ See e.g. Hans Lindahl, 'Give and take: Arendt and the nomos of political community' (2006) 32 Philosophy \& Social Criticism 881; Hans Lindahl, 'The Paradox of Constituent Power. The Ambiguous Self-Constitution of the European Union' (2007) 20 Ratio Juris 485; Hans Lindahl, 'The anomos of the earth: political indexicality, immigration, and distributive justice' (2008) 1 Ethics \& Global Politics 193; Hans Lindahl, 'Border Crossings by Immigrants: Legality, Illegality, and Alegality' (2008) 14 Res Publica 117; Hans Lindahl, 'A-Legality: Postnationalism and the Question of Legal Boundaries' (2010) 73 Modern Law Review 30; Hans Lindahl, 'Boundaries and the Concept of Legal Order' (2011) 2 Jurisprudence 73; Hans Lindahl, 'In between: Immigration, distributive justice, and political dialogue' (2011) 10 Contemporary Political Theory 140. 
'In the beginning was the fence', writes Carl Schmitt quoting favourably the German linguist Jost Trier. ${ }^{2}$

'In the beginning was a-legality', responds Lindahl. ${ }^{3}$

In this short essay, my modest aim is, then, to cover a few tangential surfaces that will hopefully identify certain metaphysical parallels that Lindahl shares with and has, at least partly, adopted from Schmitt. The use of the term 'metaphysical' is not intended as pejorative. For both Schmitt and Lindahl ground their subsequent analyses on spatial premises that are metaphysical to the extent that they are not necessarily founded on either epistemologically waterproof conceptualizations or deductive scientific reasoning but, rather, on world views that support the political aims of the respective projects. ${ }^{4}$ Lindahl is by no means politically a 'Schmittian' but, rather, a Schmitt-inspired democrat in the same vein as, for example, Ernesto Laclau and Chantal Mouffe. So Lindahl's Schmitt is a left-of-centre Schmitt sometimes, perhaps, ill at ease with the liberal political philosophy (e.g. Rawls, Raz, Waldron) that Lindahl also relies on.

Two points are worth noting right at the top. Firstly, Fault Lines is neither jurisprudence nor legal theory in the conventional senses of the terms. It is a philosophical - or a philosopher's - take on constitutional theory in the age of globalization. This philosophical perspective is the book's added value and what makes it stand out in the rather tedious monotony of transnational constitutionalism. Secondly, and relating to the first point, the subtitle could have well depicted the book as a 'phenomenology of a-legality'. But it is significant that it doesn't. Fault Lines is very much a 'politics of a-legality'. While it is a phenomenological study thereof, it is also a political treatise that, in the spirit of

2 Carl Schmitt, The Nomos of the Earth in the International Law of the Jus Publicum Europaeum [1950] (Telos Press, G. L. Ulmen tr, 2003) 74.

${ }^{3}$ Hans Lindahl, Fault Lines of Globalization. Legal Order and the Politics of ALegality (Oxford University Press, 2013) 155.

${ }^{4}$ On Schmitt's spatial metaphysics, see e.g. Claudio Minca and Rory Rowan, 'The question of space in Carl Schmitt' (2014) 38 Progress in Human Geography [in print] and the literature cited therein. 
Husserlian 'embeddedness', very much participates in the phenomenon that it studies. $^{5}$

The central vocabulary of Lindahl's spatial metaphysics is made up of three notions of demarcation, namely boundary, limit and fault line. Later a fourth, that is, frontier, is introduced, but as the 'spatial limit of a legal order', a frontier seems to denote concrete territoriality rather than a world view. ${ }^{6}$ For Lindahl, a boundary is a dividing line proper to the legal order that regulates behaviour by determining the normative premises of human action: who ought to do what, where, and when. Boundaries are, then, internal to the legal order and a spatial expression of the normative nature of law. A limit, on the other hand, is the outer perimeter that separates the legal order or, to be more exact, what is ordered by law from what is not ordered by law. So strictly speaking only a boundary can be 'transgressed' whereas a limit could only be factually 'crossed'. But limits are worth noting here to the extent that Lindahl's spatial metaphysics implies the existence of an extra-legal domain of practical possibilities that are not regulated by the normative boundaries of a legal order. These possibilities are, then, neither permitted nor prohibited as legal regulation does not apply to them. They merely remain possible.

With limits Lindahl is already at the outer edges of what standard legal theory can accommodate. But he wishes to take his analysis one step further. When we throw 'a-legality' into the mix, Lindahl, in a manner of speaking, positions himself on the Mount Olympus of high theory and, just like the a-legalities that intrude into the order of (il)legality, entertains himself by observing the 'strange behaviour and situations that, evoking another realm of practical possibilities, question the boundaries of (il)legality."7 This is not to imply that Lindahl finds anything amusing in the real world events that the theory wishes to address. Quite the contrary, Lindahl's book is motivated by a genuine concern for the

${ }^{5}$ Despite the ubiquity of Husserl and Alfred Schütz that stretches across the book's 300 pages, Lindahl's phenomenology seems to be, at least to this reader, closer to, say, Max Scheler.

${ }^{6}$ Lindahl (n 3) 52-3.

${ }^{7}$ Ibid 3. 
inability of legal theory to account for a world gone haywire. Fault lines appear when such strange events, originating in the extra-legal domain of a-legality, reshuffle the cards allowing for entirely new games to be played. And Lindahl suggests that this is also when the normative boundaries of what is legal and what is illegal come into question:

The boundaries of a legal order appear as normative fault lines to the extent that a-legal behavior and situations raise normative claims that surpass the range of practical possibilities which the apposite legal collective could actualize as its own possibilities by reconfiguring the boundaries of who ought to do what, where, and when. A fault line manifests itself in the form of normative claims that are not merely unordered but also unorderable for a given legal collective. ${ }^{8}$

This spatially articulated starting point can be rephrased in Schmittian terms. The divide between what is legally ordered and what is not also marks, in Schmitt's vocabulary, the tension between firm land and open sea, or, to put it in more metaphysical terms, between the elements of earth and water. In The Nomos of the Earth, Schmitt famously develops his 'primal scene' ${ }^{9}$ in which the originary legal order is grounded in a land-appropriation, in a first act of territorial acquisition that marks out the borderlines of the pastureland separating it from the surrounding wilderness. ${ }^{10}$ Land-appropriation, these 'great primeval acts [Ur-Akte] of law',11 the 'terrestrial fundament [Urgrund], in which all law is rooted, in which space and law, order and orientation meet'12, establishes the first legal order by defining what Lindahl would call the 'limit', a demarcation line beyond which lies an unordered domain of non-law. The essential Schmittian trademark in this 'primal scene' is the tension that the landappropriation creates between what is legally ordered - here represented by land acquired for the purposes of cultivation - and the unordered surroundings

\footnotetext{
8 Ibid 3-4.

9 The Freudian allusion is here intentional.

10 Schmitt (n 2) 70.

11 Ibid 44.

12 Ibid 47.
} 
that represent, one the one hand, an opportunity for new acquisitions and conquests and, on the other hand, the threat of being annihilated as the target of someone else's imperialistic aspirations. Opportunities and threats, for their part, are also another way of expressing the existential enmity that, for Schmitt, is the prerequisite of the political.

But what would the political mean in this instance?

Schmitt claimed that the word 'political' was being used without proper distinction and in a negative way by setting it up against what it was not like religion, culture, society, law, science, and so on. And so he insisted that the political be conceptualized 'positively' by identifying categories that are specific to it. This is the point at which Schmitt introduces the infamous friend/enemy distinction. ${ }^{13}$ Schmitt's enemy is not simply some trivial personal rival but represents the potential of factual conflict and even existential annihilation. Such an existential enemy is also made public, a hostis publicus, then, in two different ways, rather than something or someone merely lacking the qualities worthy of friendship. Consequently, Schmitt concludes, all concepts, expressions and words in so far as they are political are by nature polemical and aim at defining concrete oppositions. ${ }^{14}$

So for Schmitt the friend/enemy distinction is not really a 'conceptual' distinction at all that one would encounter as some sort of necessary binary logic. No, it is a distinction that has to be made before it can exist. It can only come about by identifying and appointing an enemy and by making it public. In a similar way, Schmitt's own attempts at formulating a 'concept' of the political are not based on epistemologically controlled analyses of the way in which the distinction plays out in the domain of politics. Because the 'concept' is itself political, the 'conceptualization' must also take place as a polemical engagement with some apolitical 'enemy'. And as is well known, for Schmitt such an 'enemy'

${ }^{13}$ Carl Schmitt, The Concept of the Political [1927] (University of Chicago Press, Expanded edn, George Schwab tr, 2007) 26.

14 Ibid 31-2. For Lindahl's own take on Schmitt's enmity, see Lindahl (n 3) 179-80. 
was the neo-Kantian variant of continental legal positivism and its Rechtsstaat principle represented by the likes of Kelsen and Paul Laband. ${ }^{15}$

A similar 'double bind' seems to characterize Lindahl's book, as well. Just as Schmitt cannot conceptualize the political from an apolitical position but will have to present the friend/enemy distinction itself as some kind of polemical intervention, so too must Lindahl 'politicize' his phenomenology into an intervention into the traditions of legal theory. In other words, Lindahl's theory is itself an 'a-legality', an intrusion - an 'irruption', as Lindahl would probably say - from the domain of what is neither legal nor illegal into the order of the law. It is not merely an 'external point of view' in the Hartian sense but, rather, a deliberate and polemical challenge. This is the 'agonistic' element of Fault Lines, the reason why Lindahl's phenomenology has to be a 'politics of a-legality' rather than 'strenge Wissenschaft' in any Husserlian sense. ${ }^{16}$ Through the a-legal irruption the order of (il)legality is opened up for politics.

As Schmitt's political world now becomes divided into friendly and hostile entities, conflict, strife and war become its ultimate possibilities. What characterizes political existence within these possibilities is a constant tension, a ceaseless anticipation of an 'a-legal irruption' that may, of course, never occur. How, then, does the existential tension configure in Schmitt's spatial metaphysics?

Schmitt dedicates much time to the analysis of what he calls 'primeval words' (Urwörte). ${ }^{17}$ Schmitt will, for example, insist that his work is not the application

15 On Schmitt's political constitutional theory, see Panu Minkkinen, 'Political constitutionalism versus political constitutional theory: law, power and politics' (2013) 11 International Journal of Constitutional Law 585.

16 There is, e.g., a certain resemblance in the way in which Lindahl describes the 'interruptive' quality of a-legal events and Jacques Rancière's thesis on politics as a rupture or break in the logic of the arkhè. See e.g. Jacques Rancière, 'Ten Theses on Politics' in Jacques Rancière, Dissensus. On Politics and Aesthetics (Continuum, Steven Corcoran tr, 2009) 27-44.

${ }_{17}$ See e.g. Schmitt (n 2) 70, footnote 10. For a critical assessment, see Bruno Bosteels, 'The Obscure Subject: Sovereignty and Geopolitics in Carl Schmitt's "The Nomos of the Earth."' (2005) 104 South Atlantic Quarterly 295. 
of a given philosophy to legal phenomena but, rather, the 'development of concrete concepts from the immanence of a concrete legal and social order.' ${ }^{18}$ So we are not talking about any applied philosophy like a 'phenomenology of law' but, rather, about a metaphysics that is extracted from an immanent and concrete legal order although it is, of course, not entirely clear what 'concrete' here means. ${ }^{19}$ Lindahl, on the other hand, has a very specific understanding of 'concreteness', ${ }^{20}$ but for him the existence of his four dimensions of space, time, subjectivity and content are the bracketed constituents of a normative phenomenology that precede any given legal order. They are, as it were, the constituents with which an order can be identified, albeit 'heuristically', as legal.

So for Schmitt, political history unfolds from his 'primal scene' as a sequence of conquered orderly spaces that he identifies with the help of the elements as 'primeval words': earth, water, air and fire:

For our historical analysis ... we retain the four elements, with their simple but evocative names. As a matter of fact, they are global designations of the various possibilities of human existence. So, we may keep on using them while talking particularly of land powers, on the one hand, and maritime powers, on the other, in the sense conveyed by these elements. ${ }^{21}$

As a sequence of appropriated elements, the world that we inhabit expands gradually from a basic territorial existence as a succession of new conquests until the whole world has been 'globalized' and, ultimately, 'depoliticized'. But any consecutive appropriation of an element must be grounded in an original

${ }^{18}$ Carl Schmitt, 'Die Lage der europäischen Rechtswissenschaft' in Carl Schmitt, Verfassungsrechtliche Aufsätze aus den Jahren 1924-1954. Materialen zu einer Verfassungslehre (Duncker \& Humblot, 1958) 386-429, 427.

${ }^{19}$ See e.g. Mika Ojakangas, A Philosophy of Concrete Life. Carl Schmitt and the Political Thought of Late Modernity (Peter Lang, 2006).

${ }^{20}$ E.g. Lindahl (n 3) 24-5.

${ }^{21}$ Carl Schmitt, Land and Sea [1954] (Plutarch Press, Simona Draghici tr, 1997) 4. See also e.g. Plato, Timaeus, 48b. 
land-appropriation, a decisionist feature not entirely unlike the appointment of an enemy that was the prerequisite of all things political:

Not only logically, but also historically, land-appropriation precedes the order that follows from it. It constitutes the original spatial order, the source of all further concrete order and all further law. It is the reproductive root in the normative order of history. ${ }^{22}$

So even if orderly space expands as successive appropriations of the elements, everything must first be grounded in an original land-appropriation that precedes all others. The original order of nomos is 'the immediate form in which the political and social order of a people becomes spatially visible - the initial measure and division of pastureland, i.e., the land-appropriation as well as the concrete order contained in it and following from it'. ${ }^{23}$ Lindahl has no such aition, nor does he need one. 'In the beginning was a-legality'24 from which the (il)legal order arises.

In another context Schmitt further elaborates his notion of space making reference to a 'contemporary German philosopher': 'it is not the world that is in space, but rather it is the space that is in the world. ${ }^{25}$ What Heidegger, Schmitt's 'contemporary German philosopher', actually says is this:

Space is not in the subject, nor is the world in space. Space is rather 'in' the world in so far as space has been disclosed by that Being-in-the-world which is constitutive for Dasein. ${ }^{26}$

The world in which Dasein dwells is, in other words, primary in relation to spatial demarcations. What Schmitt here adopts from Heidegger is an

\footnotetext{
22 Ibid 47.

${ }^{23}$ Schmitt (n 2) 70.

24 Ibid 74.

25 Schmitt (n 21) 59.

${ }^{26}$ Martin Heidegger, Being and Time [1927] (Basil Blackwell, John Macquarrie and Edward Robinson tr, 1962) 146.
} 
understanding of space as an orderly framework of the world that contains within itself the existential tension of the political. So political existence is secondary in relation to Dasein's Being-in-the-world. Lindahl's phenomenologically tuned understanding of the world as meaning-relations is much indebted to this Heideggerian idea. ${ }^{27}$ But much like in the case of Schmitt, his primary interest is 'ontic' rather than ontological. Lindahl is also more concerned with the phenomenon of law rather than with the 'fundamental ontology' of how Being unfolds for Dasein. This focus will inevitably also steer his readings into particular directions.

So political existence as Schmitt understands it includes within itself an inclination to appropriate the world, and this inclination, in turn, is animated by the existential tension created between an originary territorial locality and its outside, between 'firm land and open sea'. From this elemental relationship between earth and water, Schmitt then develops his notion of nomos as the unity of orientation and order, of Ortung and Ordnung. The sea represents a point beyond the territorial order of the land, a free and 'unordered' domain open for trade and conquest. Although it would seem that the freedom of the sea would in many ways be analogous to the 'unorderly' nature of Lindahl's a-legal domain, Schmitt's terrestrial order 'requires' the sea in a similar way as the norm and normality are logically dependent on the exception. ${ }^{28}$ Because that order is by definition also political, it presupposes an external point of 'enmity': 'the state is the political status of an organized people in an enclosed territorial unit.'29

A maritime expansion from land to sea will extend the nomos of the earth 'elementally' to water:

27 E.g. Lindahl (n 3) 262-4.

${ }^{28}$ Carl Schmitt, Political Theology. Four Chapters on the Concept of Sovereignty [1922] (University of Chicago Press, George Schwab tr, 2005) 12-3.

${ }^{29}$ Schmitt (n 13) 19. 
Such extensions of law to the space of the free sea were world-historical events of revolutionary significance. We will call them 'seaappropriations.'30

In these 'world-historical' and 'revolutionary' epochal extensions, the order of nomos is eventually broadened from a 'global' conception of the world in which the distinction between earth and water still sustains the existential tension of the political to a 'planetary' conception of the world. A planetary conception is established from an aerial position, that is, by appropriating the element of air:

Aware as one is that airplanes crisscross the air space above seas and continents, and the waves broadcast by transmitters in every country cross the atmosphere and circle the globe in a matter of seconds, one is tempted to conclude that man has conquered not only a third dimension, but also the third element, air, the new elemental space of human exis-tence. To the two mythical creatures, leviathan and behemoth, a third would be added, quite likely in the shape of a giant bird. ${ }^{31}$

And, finally, the remaining element of fire represents the ultimate nuclear threat of a world entirely submitted to technology. The extensions that appropriate the elements one by one are also Schmitt's account of the process of gradual globalization. And the epochal successions of ever new nomoi will inevitably lead to the world closing in on itself as the original distinction between earth and water collapses and the existential tension of the political that it included within itself is annulled. A completely globalized world is, then, also a depoliticized world. But we're not quite there yet, for:

... the forces and the powers that forge history wait for science to make up its mind as little as did Christopher Columbus and Copernicus. Each

\footnotetext{
${ }^{30}$ Schmitt (n 21) 44.

31 Ibid 57-8. On the 'two mythical monsters', see Carl Schmitt, The Leviathan in the State Theory of Thomas Hobbes. Meaning and Failure of a Political Symbol [1938] (University of Chicago Press, George Schwab and Erna Hilfstein tr, 2008) 5-15.
} 
time the forces of history cause a new breach, the surge of energy brings new lands and new seas into the visual field of human awareness, the spaces of historical existence undergo a corresponding change. Hence, new criteria appear, alongside of new dimensions of political and historical activity, new sciences, new social systems [neue Ordnungen]; nations are born and reborn. This redeployment may be so profound and so sudden that it alters not only man's outlook, standards and criteria, but also the very contents of the notion of space. ${ }^{32}$

This account of 'spatial revolutions' sounds very much like the dynamic of a-legal irruptions that also maintain the politics of (il)legality. A-legality is the politics of (il)legality.

Fault Lines begins with a wonderful anecdote about a homeless clochard and a shared meal. ${ }^{33}$ It represents the type of unexpected intrusion of life into our orderly world that sometimes - not always - allows us to see beyond what we thought was possible. Lindahl's anecdote is an echo of how Heidegger describes the ways in which Dasein is absorbed in its world of equipment - for example, the orderly environment of the restaurant - until we are interrupted by something 'un-ready-at-hand' that lights up that world and the equipmental space in which we as Dasein dwell. ${ }^{34}$

But what is the status of this a-legal intrusion and the fault line that it draws? The incident did take place, as Lindahl will testify, and so it was always a possibility. As a possibility, it was already included within the range of potential scenarios that the ordered domain of the restaurant as a 'world' could actualize. Always already, as one might also say.

${ }^{32}$ Schmitt (n 21) 29; Carl Schmitt, Land und Meer. Eine weltgeschichtliche Betrachtung [1954] (Klett-Cotta, 4th edn, 2001) 56-7.

33 Lindahl (n 3) 1-4.

${ }^{34}$ Heidegger (n 26) 102-7 and Lindahl (n 3) 263-4. See also Panu Minkkinen, Thinking Without Desire. A First Philosophy of Law (Hart, 1999) 54-60. 